\title{
Malnutrition: Causes and Strategies
}

\author{
Kaiser Younis, Saghir Ahmad* and Abdolghafour Badpa
}

Department of Post-Harvest Engineering and Technology, Aligarh Muslim University, Aligarh, UP, India

\begin{abstract}
Malnutrition is estimated to contribute to more than one third of all child deaths, although it is rarely listed as the direct cause. At the global level, a science and technology initiative is required to solve the listed problems such as increasing food prices, economic recession, increased competition for natural resources and climate change. Diseases like cancer, HIVIAIDS, oral health and chronic renal failure also breakdown the nutritional status. Bio fortification, probiotic foods and food processing strategies have shown the potential to overcome the malnutrition. A recently developed home based treatment for severe acute malnutrition is recovering the lives of hundreds of thousands of children a year. Ready-to-use Therapeutic Food (RUTF) has changed radically the treatment of severe malnutrition - providing foods that are safe to use at home and ensure quick weight gain in severely malnourished children. This review of the literature throws light on the causes of malnutrition and some important strategies like bio fortification, therapeutic diets, prebiotic foods and food processing to overcome malnutrition.
\end{abstract}

Keywords: Malnutrition; Bio fortification; Fortification; Probiotics; Therapeutic food

\section{Introduction}

Malnutrition is defined as "a state of nutrition in which a deficiency, or excess, of energy, protein and micronutrients causes measurable adverse effects on tissue/body form (body shape, size and composition) and function, and clinical outcome" [1]. However, in case of under-nutrition, this definition does not take into account the cause of unintentional weight loss. Unintentional weight loss may have three primary syndromes: starvation, sarcopenia and cachexia $[2,3]$. Starvation generally occurs as a result of protein-energy deficiency and is synonymous with PEM. The main difference between starvation and other syndromes of unintentional weight loss is that it is reversed when adequate energy and protein intake is achieved [4]. In sarcopenia there is a progressive loss of muscle mass that occurs with normal ageing though this area is still under investigation [5-7]. Dietary management alone would be unlikely to address weight loss as sarcopenia is thought to occur regardless of energy balance $[8,9]$. Cachexia is caused by proinflammatory cytokines and is associated with a number of chronic conditions such as cancers, HIV/AIDS, heart failure and chronic obstructive pulmonary disease (COPD). A group of prominent researchers together develop a consensus definition for cachexia which indicates that "cachexia is a complex metabolic syndrome coupled with underlying illness and characterized by loss of muscle with or without the loss of fat [10]. Malnutrition is classified on the basis of what nutrients are absent in the diet, for how long and at what age. There are two major types of malnutrition which have been further divided as shown in the Table 1.

Deficiency in energy balance and protein are characteristics of malnutrition, which may impair the proper functioning of various physiological processes [11]. Even though, obese patients can also have malnutrition but it is mainly used synonymously with under nutrition [12]. About, $14 \%$ of world population was affected by malnutrition in 2008 [13]. At a later stage of the life, the risk factors which are considered to prompt cardiovascular and metabolic disease are the perinatal malnutrition and slowed weight gain at birth $[14,15]$. In the policy discussions on food security micronutrient malnutrition has taken center stage. It is accepted that food security does not refer to just providing adequate energy intakes only but also to ensuring sufficient intakes of essential micronutrients. The diets of developing countries are deficient in vitamin A, iron, and zinc. Estimated number of micronutrient malnutrition affected people is high. Up to 5 billion people are suffering from the deficiency of iron and almost 130 million of all pre-school children are suffering from the deficiency of vitamin A [16]. It was estimated that $25-33 \%$ population of the developing countries was at the risk of inadequate zinc intake [17].

\section{Causes of Malnutrition}

\section{Climate}

Food production of many Sub-Saharan Africa countries, which is often affected by environmental conditions (i.e. soil fertility, rainfall, temperature), face the risk of failing food availability as indications of warming climates on current food systems $[18,19]$. There is an increasing strain on food resources due to climatic factors as well as due to decreasing of land area suitable for planting and agricultural production [20]. These changes (reducing the area suitable for cultivation and climatic change) may accelerate food shortages and may, therefore, lead to an increase in child malnutrition. According to the World Food Summit and the Food and Agriculture Organization, there are three core aspects of food security which includes: 1) availability, 2) access, and 3) utilization [21]. Although, the current food security policy which mostly focuses on access and availability of food, is still a basic component of food security. Furthermore, the actual availability of food can be largely impacted by agricultural production and variation in climate patterns. Climate patterns, namely rainfall and temperature, are the variables which proportionally increase with the onset of global climate change, and hence the relationship between agricultural production and climate is of increasing notice and alarm [22].

\section{Food price}

From the time of high food prices in the 1870's the world population has amplified more than five times and has attained

*Corresonding author: Saghir Ahmad, Research Scholar, Department of PostHarvest Engineering and Technology, Aligarh Muslim University, Aligarh, UP, India, Tel: +919412601092; E-mail: alsaghirqadri@gmail.com

Received February 22, 2015; Accepted March 10, 2015; Published March 17 2015

Citation: Younis K, Ahmad S, Badpa A (2015) Malnutrition: Causes and Strategies. J Food Process Technol 6: 434. doi:10.4172/2157-7110.1000434

Copyright: $\odot 2015$ Younis K, et al. This is an open-access article distributed under the terms of the Creative Commons Attribution License, which permits unrestricted use, distribution, and reproduction in any medium, provided the original author and source are credited. 


\begin{tabular}{|c|c|c|}
\hline Types of malnutrition & Disease & Deficiency \\
\hline \multirow{2}{*}{$\begin{array}{c}\text { Protein energy } \\
\text { malnutrition }\end{array}$} & Kwashiorkor & Protein \\
\cline { 2 - 3 } & Marasmus & Protein \\
\hline \multirow{4}{*}{$\begin{array}{c}\text { Osteoporosis } \\
\text { Rickets } \\
\text { Tetany }\end{array}$} & Calcium \\
\cline { 2 - 3 } & Goiter & lodine deficiency \\
\cline { 2 - 3 } minerals & Keshan & Selenium \\
\cline { 2 - 3 } & Anemia & Iron \\
\cline { 2 - 3 } & Growth retardation & Zinc \\
\cline { 2 - 3 } & Beriberi & Thiamine (Vitamin $\mathrm{B}_{1}$ ) \\
\cline { 2 - 3 } & Pellagra & Viacin (Vitamin $\mathrm{B}_{3}$ ) \\
\cline { 2 - 3 } & Scurvy & Vitamin C \\
\cline { 2 - 3 } & Osteoporosis \\
& Rickets & Vitamin D \\
\hline
\end{tabular}

Table 1: Types of malnutrition.

6.7 billion today. It is expected nearly to reach 9 billion in 2050. To overcome existing hunger and to provide food to a further 2 billion people, food production has to be increased to double by 2050. IFPRI has estimated that recession and reduced investment in agriculture can increase international food prices by $30 \%$ and thrust 16 million more children into malnutrition in 2020 when compared to the present high economic growth and maintained investments [23]. Increase in food prices too has adversely affected micronutrient deficiencies which gave desirable results on nutrition and health of people. For example, impaired cognitive development, weak immune system and increased risks for mothers as well as children during childbirth. Since nutrition is important for physical and mental development of children and it is directly related to their earnings in adulthood. A 2008 Lancet article shows that there were $50 \%$ higher wages to those people who advantaged from a randomized nutrition intervention when they were young children than those of nonparticipants three decades later [24]. Numerous studies have shown that investing in the field of research and development of agriculture is one of the useful tools to promote growth and reduce poverty. For example, in India in the 1990's spending of 1 million rupees on agricultural research and development will lift 323 poor people above the poverty line [25].

\section{Diseases}

Cancer: In numerous publications it has been reported that malnutrition is a common problem in pediatric patients with cancer and its clinical relevance has been widely accepted by professionals [2630]. Malnutrition in pediatric patients with cancer is mainly due to an inadequate intake of food and desorption of nutrients. This is because of the gastrointestinal side effects of cancer therapy, primary effects of cancer itself, and changes in metabolism [31-35]. Chemotherapy, high infection rates and overall reduction of body defense mechanisms have been associated with malnutrition [36,37]. Reported occurrence of malnutrition varies widely ranging from $8 \%$ up to $60 \%$ in pediatric patients with cancer, depending on type of cancer, treatments, methods used to determine under nutrition, for example, BMI $\mathrm{z}$-scores/percentile, weight/length $\mathrm{z}$-scores/percentile, and operational definitions.

HIV/AIDS: Malnutrition and HIV/AIDS are badly interrelated with each other. HIV infection increases the susceptibility to malnutrition and malnutrition on the other hand degrades the immune system and increases the susceptibility to HIV transmission risk and disease progression [38,39]. Children may get affected directly by HIV/AIDS infection from vertical transmission and the recent studies showed that HIV-infected children are more likely to suffer from malnutrition $[40,41]$ and their survival is also at peril $[42,43]$. Nalwoga et al. [41] studied the nutritional status of rural Uganda children with high prevalence of HIV and observed that the chance of under nutrition was significantly higher in HIV positive than in HIV negative children. Same trend was shown by earlier findings from other settings in sub-Saharan Africa. Further, parental illness and death as a result of HIV/AIDS may affect children. It has been studied that children born to HIV positive women die before the age of five than others and this risk applies to those who are HIV infected themselves [44].

Oral health of geriatric patients: Malnutrition in the elderly is a complex and multi-factorial problem. Particularly, when they need to reside in a long-term care facility they are susceptible to malnutrition. The Oral health of aged people has a negative impact on quality of life. Malnutrition in the elderly population is an under-assessed and undermanaged problem [45]. International variation has been seen in the malnutrition of elderly people due to the variations in differences in population study, use of different definitions and difference in methods to measure malnutrition. It has been reported that $30-90 \%$ of the hospitalized geriatric patients [46-48], 30-50\% of the institutionalized elderly $[49,50]$ and $4.3-44 \%$ of the community resident older persons are malnourished [51]. More precisely, ageing is linked with problems in oral health like loss of teeth, caries, oral dryness, periodontal diseases, painful mucosal disorders and decreased masticatory functioning [52]. The consumption of food is reduced due to oral health status because the loss of chewing ability, taste perception and the capacity to swallow it. It has been seen that institutionalized elders have poor oral health mostly due to loss of independence in the elderly, difficulty in accessibility and affordability of oral care [53].

Chronic renal failure: Malnutrition is normally seen with chronic renal failure patients. They have reduced body weight, loss of somatic protein (low muscle mass), depleted energy (fat tissue) stores and low levels of serum albumin, pre-albumin, transferrin and other visceral proteins. Several studies illustrate signs of malnutrition in $18-50 \%$ of peritoneal dialysis and $23-76 \%$ of hemodialysis patients [54-57]. The above variations in the occurrence of malnutrition may be due to the factors like aging, case mix, co-morbid conditions and quality of dialysis therapy. The cause of malnutrition in chronic renal failure is complex and may comprise several factors, e.g. reduced food intake because of appetite, nausea and vomiting due to uraemic toxicity, hormonal imbalance, acidosis and increased resting energy expenditure.

It is to be considered that two types of malnutrition may occur in dialysis patients. The first type is related to uraemic syndrome or its associated factors and is characterized by decrease in serum albumin levels. The protein and energy malnutrition initial signs start early in the course of progressive renal failure and the growth of renal failure is linked with a spontaneous reduce in dietary protein intake $[58,59]$. In this type of malnutrition resting energy expenditure may be normal but due to uraemic anorexia there is a corresponding decrease in protein catabolism and co-morbid for example chronic heart failure and elevated levels of pro-inflammatory cytokines are generally not present. In second type of malnutrition higher resting energy expenditure, marked hypoalbuminaemia, markedly increased oxidative stress and protein catabolism and co-morbid conditions, for example chronic heart failure, frequently are found in this type of malnutrition.

\section{Strategies for Malnutrition}

\section{Biofortification}

Micronutrient malnutrition is often called hidden hunger and is a serious health problem throughout the world [60]. Biofortification 
is the process of breeding; where the food crops which are rich in bioavailable micronutrients for example vitamin A, zinc, and iron etc. are "biofortified" by loading higher levels of minerals and vitamins in their seeds and roots during growth. Unlike common fortification which needs repeated addition of particulate nutrient, biofortification is a one-time investment in dissemination of nutrient-dense varieties and becomes self-sustaining. With the help of biofortification, scientists can provide farmers with crop varieties that provide essential micronutrients that can naturally decrease anemia, cognitive impairment, and other malnutrition related problems which have affected billions of people. For example, in Philippines a 9-month feeding trial of rice containing an additional 2.6 (PPM) of iron showed efficacy in improving body iron stores among iron deficient women [61]. Likewise, a feeding trial of orange sweet potato with school children in South Africa showed improvements in their vitamin A status due to high beta-carotene [62]. A similar effect was also obtained in a community living in Mozambique [63]. The few examples of biofortified crops are shown in Table 2.

In developing countries the most common micronutrient deficiency is iron deficiency which has affected about $40 \%$ of the world's population, particularly women and children [64]. Iron deficiency is mainly among the population having low-income where consumption of meat is not affordable and their regular diets are cereals and legumes which contain inhibitors of iron absorption [65-68]. Therefore, a main reason of iron deficiency is low bioavailability from plant-based foods containing iron bioavailability inhibitors such as polyphenols [6670]. In the past, policies aimed to fortify iron in the diets to improve iron deficiency anemia. On the other hand, these plans are difficult to maintain because of high cost, limited access to health care, the partial availability of centralized food processing facilities required for postharvest crop fortification, and other limiting logistical factors [7173]. Development has been made during the last decade to develop a higher Fe content and/or bioavailability cereal and legume crops [7476]. This approach is well-known as biofortification [77].

\section{Probiotic foods}

In African continent the incidents of diarrhoea are high, which is a main cause of child mortality of less than five years old. The consumption of fermented foods containing probiotics will be one of the opportunity by which health of children may be improved. Fermentation is a preservation technique, hence can prevent post harvest losses, detoxifying the raw materials as well as increasing the intake of nutrients, thus alleviating malnutrition [78]. A study conducted on Kenyan cowpea leaves which were fermented and solar dried, showed reduced anti-nutrients and increased acceptability of the product, hence potentially alleviating micronutrient malnutrition [79]. Fecal microbiota of African children with health problems was investigated which showed that anemic children from the Ivory Coast carry an adversely high ratio of fecal enterobacteria to bifidobacteria and lactobacilli, which was even increased by iron fortification [80]. An additional study on Malawian children that appeared to be characterized by Bilophila wadsworthia, a bacterium linked to inflammatory bowel disease, and Clostridium innocuum, a species which can function as an opportunist in immune compromised hosts, showed that the gut microbiota was an underlying factor in the development of kwashiorkor, an enigmatic form of severe acute malnutrition [81]. From the above studies it was concluded that in healthy African children a diet higher in fiber and carbohydrates appears to select the useful gut microorganisms which in turn help to protect against infection, inflammation as well as extracts the maximum energy from the low calorie food. This supports the use of African indigenous fermented plant foods which acts as vehicles for probiotics. Fermented foods affect the gut microbiota and can be useful in terms of diseases like anemia or severe under nutrition. Probiotics have immune stimulatory activity and restoration of gut functionality by stimulating the diversity of bacteria $[82,83]$. Delivering of probiotic products to Africa which can improve the lives of hundreds and millions of people elsewhere is tantamount to neglect. However, for those trying to make a difference, solutions are slowly being explored. These include: (i) the establishment of networks in which local people can set up their own kitchens and produce probiotic foods; (ii) the isolation of African bacterial strains from traditional foods, and developing them for probiotic applications; and (iii) attempts to commercialize fermented food processing to account for regional variations in raw materials, recipes and production methods [84], and starter culture technology [85].

\section{Therapeutic diet strategies F75 and F100 or RUTF}

The major public health problem throughout the developing world, mainly in sub-Saharan Africa and South Asia is severe acute malnutrition (SAM). Approximately 20 million children million suffer from SAM. Commercially available remedial formulas to cure SAM are (F-75 and F-100) and ready-to-use therapeutic foods that meet specified standards with the WHO specifications are fortified with vitamin $\mathrm{A}$. This has gained the central attention whether it is safe to give high dose of vitamin A to children with severe acute malnutrition, mainly those with oedema and hepatic dysfunction [86]. Patients with no adequate appetite and/or have a major medical complication are initially admitted to in-patient facilities. The formula which is used at this stage is F75. It promotes recovery of normal metabolic function and nutrition electrolytic balance. At this stage rapid weight gain is precarious, that is why F75 is formulated so that patients do not gain weight during this stage. Once children with severe acute malnutrition are stabilized in inpatient care, it is recommended to change the therapeutic diet to F-100 or a ready-to-use therapeutic food. This enables the recovery of weight and lean body tissue loss [87].

RUTF is a broad term including different types of foods, such as compressed or spreads products, purposely designed for the treatment of SAM. The energy density of RUTF is very high about $23 \mathrm{~kJ} / \mathrm{g}(5.5$ $\mathrm{kcal} / \mathrm{g}$ ) [88]. Generally it consists of a mixture of milk powder, vegetable oil, sugar, peanut butter and a vitamin-mineral premix. Since bacteria growth in RUFT is limited and can be stored safely at home without refrigeration, it can be used even in areas where hygienic conditions are not optimal because it does not need water, utensils etc., before taking it. Considerable time, work, effort and money are saved in the care for SAM cases by using ready-to-use nature of the foods. The composition of RUTF has precisely specified by international organizations such as WHO, UNICEF and WFP. Many studies have showed the acceptability and effectiveness of RUFT mainly in Africa for the treatment of SAM [89-92]. Thus, both in non-emergency situations and in disaster relief programs the RUTF treatment has been recommend for SAM by the World Health Organization and UNICEF. In recent years RUTF has steadily turned out to be the most extensively used therapeutic resolution to fight child malnutrition. Thriving experiences have been reported in Ethiopia [93], Malawi [94,95], Niger [96,97], Kenya [98], Sudan [99] and Sierra Leone, among others.

\section{Food processing strategies}

Food processing has a main role and huge potential in both to increase dietary diversity and to enhance concentrations of micronutrients in frequently consumed foods. At the moment, food processing is applied to preserve foods, enhance food safety, add 


\begin{tabular}{|c|c|c|c|c|}
\hline S No. & Biofortified substance & Method of Biofortification & Plants & References \\
\hline 1 & lodine and selenium & $\begin{array}{c}\text { Applied foliarly or through the nutrient medium in the hydroponic system of nutrient } \\
\text { film technique }\end{array}$ & Lettuce & [110] \\
\hline 2 & Selenium & Foliar spraying & $\begin{array}{l}\text { Onions and } \\
\text { Carrots }\end{array}$ & [111] \\
\hline 3 & $\mathrm{Fe}, \mathrm{Cu}, \mathrm{Zn}$ and $\mathrm{Mn}$ & $\begin{array}{l}\text { Rhizobacteria: Providenciasp PW5; cyanobacterial: Anabaenasp CW1, Calothrixsp CW2. } \\
\text { Anabaenasp CW3. }\end{array}$ & Wheat & [112] \\
\hline 4 & Zinc & $\mathrm{Zn}$ fertilization and Foliar $\mathrm{Zn}$ applications & Rice & [113] \\
\hline 5 & Selenium & Growing wheat plants with co-inoculation of selenobacteria and arbuscular mycorrhizal fungi & Wheat & [114] \\
\hline 6 & Protein, Fe and $\mathrm{Zn}$ & Arbuscular mycorrhizal fungi (AMF) symbiosis with chickpea & Chickpea & [115] \\
\hline 7 & lodine & I fertilization & Spinach & [116] \\
\hline 8 & Zinc & Inoculation of zinc solubilizing Bacillus aryabhattai strains & $\begin{array}{l}\text { Soybean } \\
\text { And wheat }\end{array}$ & [117] \\
\hline 9 & Selenium & Inoculation of Arbuscular mycorrhizal fungi & Lettuces & [118] \\
\hline 10 & Selenium & Agronomic and/or genetic approaches & Lentil & [119] \\
\hline 11 & Selenium & Soils amended with ground shoots of the Se hyperaccumulator Stanleya pinnata. & Broccoli and carrots & [120] \\
\hline 12 & Selenium & Soil and foliar Se application & Rice & [121] \\
\hline 13 & Zinc & Fertilizer applications & Wheat & [122] \\
\hline
\end{tabular}

Table 2: Examples of some recent biofortification crops.

convenience, improve flavour, enhance nutritional value, and save energy [100]. In addition to preservation from spoilage, processing of fresh fruits and vegetables, also help to retain micronutrients. For example, there is only $30 \%$ loss of vitamin $\mathrm{C}$ in spinach when stored just after harvesting at $-20^{\circ} \mathrm{C}$ for 10 months as compared to $100 \%$ loss of vitamin $\mathrm{C}$ in fresh spinach stored at room temperature for 7 days [101]. Although the severe heat treatment of canning $121^{\circ} \mathrm{C}$ for 30 min can cause significant degradation of heat sensitive vitamins, but after caning the products are shelf stable at room temperature for long duration and the nutrient loss of canned products during storage are less than for fresh and frozen products [102]. There is a significant contribution of processed fruits and vegetables to the nutrient intakes. For example, in the US, processed fruits and vegetables provide $35 \%$ of dietary fiber, $40 \%$ of folate, $47 \%$ of potassium, $25 \%$ of vitamin A, and $51 \%$ of vitamin C [103].

\section{Impact of food waste on micronutrients in the food supply}

Food losses or food waste are considered as the major contributors to hunger and malnutrition. Indeed, reduction of food losses was one of the mandates for the Food and Agriculture Organization (FAO) of the United Nations in 1945 [104]. There is a slight difference in the definitions of "food loss" and "food waste" in literature. However the two terms are mostly used interchangeably. Both terms depict the unavailability of edible human food away from human consumption. The loss of edible food during the production and processing stages of the food supply chain is often defined as "food loss" [105]. These losses occur during harvesting to retail outlets. Some authors consider human edible food stuffs diverted to animal feed or bio-fuels to constitute losses while others do not. The losses on the other hand are defined as "food waste" if it is produced at retail and consumer levels of food supply chain. These losses depend primarily on the behaviour of retailers and consumers, e.g. when edible food is discarded because of blemishes or because the date printed on the label is close to its expiry date. Food losses occur due to various factors and can be accelerated by rodents, insects, microbial spoilage, high ambient temperatures, high humidity, enzymatic reactions in the food, etc. To find data on the amount of food waste is difficult, incomplete and possibly inaccurate. However, a recent FAO report has estimated that roughly $1 / 3$ of food produced worldwide for human consumption is lost or wasted. It has been seen that food losses and food waste are greater in the developed countries than that of developing countries on a per capital basis.
Gustavsson et al. [105] has estimated that losses plus waste of edible food in Europe and North America was 280-300 kg/person/year, in sub-Saharan Africa it was $160 \mathrm{~kg} /$ person/year and $120 \mathrm{~kg} /$ person/year in South and Southeast Asia. From the data it is concluded that greater wastes are produced by consumers in developed countries as compared to developing countries. The reason may be that the consumers in the developed countries are wealthier and have relatively abundant cheap food. Wealthy people waste completely edible foods. As people become rich, they tend to shift their diets from more carbohydrate to less carbohydrate foods like fruits, vegetables, meat, fish, and dairy [104]. These foods are more perishable than the staple food crops that they partially replace. For example, losses of cereals from production to distribution are less than $20 \%$ in developing countries than those of fruits and vegetables which is nearly $50 \%$. In the US, meat, poultry and fish account for $41 \%$ of the total value of food wasted at the retail and consumer levels. Whereas dairy products, vegetables, fruits, and grain products account for $14 \%, 17 \%, 9 \%$, and $6 \%$ of the total value of food wasted respectively [106]. There is a progressing trend toward urbanization in many countries all over the world. Policies designed to reduce food waste and food losses are immediately required in developed and developing countries in a similar way.

\section{Impact of food fortification on micronutrients in the food supply}

Food fortification is a part of food processing. The Codex Alimentarius defines food fortification or food enrichment as the addition of one or more essential nutrients to a food whether or not it is normally contained in the food for the purpose of preventing or correcting a demonstrated deficiency of one or more nutrients in the population or specific population groups. There are several types of commercial fortification programs practiced in many countries all over the world. The different types are voluntary fortification, mandatory fortification, mass fortification, and target fortification. When a food company voluntarily adds nutrients to a food which are not mandated by the government to be fortified is called voluntary fortification [107]. Governments may issue regulations for voluntary addition of nutrient which may include the concentration, types of nutrients to be added and the vehicle foods that are permitted for nutrient addition without mandating that the foods be fortified [107]. There are a lot of examples of voluntary fortification, for example in several countries processed breakfast cereals are voluntarily fortified. Mandatory fortification 


\begin{tabular}{|c|c|c|c|c|}
\hline S. No. & Deficient nutrient & Fortified foods & Fortified nutrients & References \\
\hline 1 & Calcium & $\begin{array}{c}\text { Eggplant } \\
\text { (solanum melongena I.), carrot (Daucus carota I.), and oyster } \\
\text { mushroom (Pleorotus ostreatus) }\end{array}$ & $\begin{array}{l}\text { By vacuum impregnation of isotonic solution of } \\
\text { sucrose and calcium lactate ( } 33 \mathrm{~g} \text { Suc/20 } \mathrm{g} \text { lca) }\end{array}$ & [123] \\
\hline 2 & Iron & $\begin{array}{l}\text { Sorghum (Sorghum bicolor L. Moench) and Pearl millet } \\
\text { (Pennisetum glaucum) flour }\end{array}$ & $\begin{array}{c}\text { Ethylene diamine tetra amino acid (EDTA) and folic } \\
\text { acid }(6 \mathrm{mg} / 100 \mathrm{~g})\end{array}$ & [124] \\
\hline 3 & Zinc & $\begin{array}{c}\text { Finger millet (Eleucine coracana) flour, sorghum (Sorghum } \\
\text { vulgare) and pearl millet (Pennisetum glaucum) } \\
\text { Flour }\end{array}$ & $\begin{array}{c}\text { Zinc oxide or zinc stearate ( } 50 \mathrm{mg} \text { zinc per } \mathrm{kg} \text { flour); } \\
\text { Zinc stearate with emetalchelator edta (5 } \mathrm{mg} \mathrm{zn} / 100 \\
\text { g flour) }\end{array}$ & {$[125,126]$} \\
\hline 4 & Folate & White and whole-grain bread & $\begin{array}{l}\text { Fortified with Swiss chard or spinach at } 20 \mathrm{~g} / 100 \mathrm{~g} \\
\text { and } 40 \mathrm{~g} / 100 \mathrm{~g}\end{array}$ & [127] \\
\hline 5 & Folate & Skim milk, cucumber and water melon juice & $\begin{array}{c}\text { By using lactococcus lactis sp, cremoris for } \\
\text { enhanced the folate level ((164 } \mathrm{ng} / \mathrm{ml} \text {, deconjugated } \\
\text { folate) })\end{array}$ & [128] \\
\hline 6 & Folic acid & Parboiling rice & Folic acid at $1.2 \mathrm{~g}$ folic acid $/ 300 \mathrm{~g}$ brown rice & [129] \\
\hline 7 & Fructooligosaccharides & Pineapple, Mango and Orange juice & $\begin{array}{l}\text { Fructooligosaccharides } 2000 \mathrm{~g} \text { to } 2000 \mathrm{~g} \text { fruit pulp/ } \\
\text { juice }\end{array}$ & [130] \\
\hline 8 & Calcium lactate & Mango yogurt & $\begin{array}{c}\text { Calcium lactate pentahydrate }(50 \mathrm{mg} \text { Ca per } 100 \mathrm{ml} \\
\text { of yogurt mix })\end{array}$ & [131] \\
\hline 9 & Iron & Finger millet (Eleucine coracana) flour & $\begin{array}{c}\text { Ferrous fumarate and ferric pyrophosphate were } \\
\text { added at levels that provided } 6 \mathrm{mg} \text { of iron per } 100 \\
\mathrm{~g} \text { of the flour }\end{array}$ & [132] \\
\hline 10 & Iron & Reconstituted skim milk & $\begin{array}{l}\text { Ferrous fumarate, ferric pyrophosphate, disodium } \\
\text { EDTA, folic acid } \\
\begin{array}{c}\text { And citric acid are added to the flour to provide } 60 \\
\mathrm{mg} \text { iron } / \mathrm{kg} \text { flour }\end{array}\end{array}$ & [133] \\
\hline 11 & Iron & Milk & $\begin{array}{l}\text { Iron salt (ferrous sulphate at } 25 \text { ppmiron) and iron } \\
\text { microcapsules (@25 ppm iron) }\end{array}$ & [134] \\
\hline 12 & Zinc & Reconstituted skim milk & $\begin{array}{l}\text { Zinc aspartate, zinc sulphate or zinc gluconate (16 } \\
\text { mg of } Z n^{+2} L^{-1} \text { milk). }\end{array}$ & [135] \\
\hline 13 & Fish oil & $\begin{array}{l}\text { Yoghurts, fresh, } \\
\text { Soft and processed cheeses, butter and cream }\end{array}$ & $\begin{array}{l}\text { Long-chain polyunsaturated fatty acid } \\
\text { (pufa) omega-3 }\end{array}$ & [136] \\
\hline 14 & Vitamin D3 & $\begin{array}{l}\text { Cheddar cheese-like } \\
\text { Matrix, yogurt and ice cream }\end{array}$ & $\begin{array}{c}\text { Pre-dissolved crystalline vitamin D3 and emulsified } \\
\text { vitamin D3 }(100,000 \text { ium L-1) }\end{array}$ & [137] \\
\hline 15 & Whey protein & $\begin{array}{l}\text { Wheat starch, as a model high-protein-low carbohydrate (HPLC) } \\
\text { food }\end{array}$ & Whey protein isolate (20 and $50 \%$ ) & [138] \\
\hline 16 & Zinc & Parboiled rice (cv. SPR 1 and CNT 1) & Zinc sulfate and oxide ( $50-400 \mathrm{mg} \mathrm{Zn/kg}$ paddy rice) & [139] \\
\hline
\end{tabular}

Table 3: Examples of some recent work on fortified food.

is compulsory addition of nutrient according to laws or regulations issued by government which are required for the fortification of certain foods [107]. This type of fortification is performed in the countries where there are widespread nutrient deficiency diseases or low intakes of a particular nutrient, clear public health need and where consumer knowledge about nutrition is limited [107]. Mass fortification describes the addition of nutrients to foods which are commonly consumed (wheat flour or rice) by all segments of population to prevent the assumed risk of a particular nutrient deficiency in that population [107]. And finally to eradicate a unique risk of nutrient deficiency in a particular group within a population, e.g. infants target fortification is done to overcome that risk. An example of target fortification is the addition of nutrients to infant formulas [107]. Food fortification is one of the best ways to have significantly benefited on the well-being of large segments of populations. The World Bank in 1994 reported about fortification as "no other technology offers as large an opportunity to improve lives at such low cost and in such a short time" [108]. Today, there are lots of people all around the world who could benefit from fortified foods but do not have access to them. Fortification of foods dates back to 1920 's when adding of potassium iodide to salt as a means of preventing goiter was done in Switzerland and the United States [109]. Until today many nutrients have been tried to fortify in different foods and some of the recent examples are shown in Table 3.

\section{Conclusion}

The aim for reducing poverty and to provide enough food with nutritional security and provide access and a compact basket of food which can provide balanced diet with adequate micro and macronutrients are required to keep good health of human being. The information received from the world shows that some specific countries are recorded as an example of malnutrition which is prevailing there. Mostly malnutrition is also prevailed due to anemia the important factor.

Biofortification has been introduced to overcome the nutritional problem and to make the important micronutrient bio-availability. It rectifies several health problems like anemia and vitamin deficiency diseases. Probiotic is one way to provide the health benefits to consumers and it can provide adequate health benefits and several diseases are controlled by using the therapeutic diets like Fructo oligosaccharides, F100, RUTF etc.

\section{Acknowledgement}

The authors would like to thank Maulana Azad Library of AMU, Aligarh for providing access to online journals. We would also like to extend our profuse gratitude to Mr. Manzoor Ahmad Najar for his kind assistance in editing the final English version of this manuscript.

\section{References}

1. Stratton RJ, Green CJ, Elia M (2003) Scientific criteria for defining malnutrition Disease-Related Malnutrition. An Evidence Based Approach to Treatment CABI Publishing Wallingford.

2. Chapman IM (2011) Weight loss in older persons. Medical Clinics of North America 95: 579-93.

3. Thomas D (2007) Loss of skeletal muscle mass in aging: examining the relationship of starvation sarcopenia and cachexia. Clinical Nutr 26: 389-99. 
4. Thomas D (2002) Distinguishing starvation from cachexia. Clinics in Geriatric Medicine 18: 883-91.

5. Cruz-Jentoft AJ, Baeyens JP, Bauer JM, Boirie Y, Cederholm T, et al. (2010) Sarcopenia: European consensus on definition and diagnosis: report of the European Working Group on sarcopenia in older people. Age and Ageing 39: 412-23.

6. Fielding RA, Vellas B, Evans WJ, Bhasin S, Morley JE, et al. (2011) Sarcopenia: an undiagnosed condition in older adults. Current consensus definition: prevalence, etiology and consequences. International Working Group on Sarcopenia. J of the American Med Directors Association 12: 249-56.

7. Muscaritoli M, Anker SD, Argilés J, Aversa Z, Bauer JM, et al. (2010) Consensus definition of sarcopenia cachexia and pre-cachexia: joint document elaborated by Special Interest Groups (SIG) "cachexia-anorexia in chronic wasting diseases" and "nutrition in geriatrics". Clinical Nutr 29: 154-9.

8. Messinger-Rapport B, Thomas D, Gammack J, Morley J (2009) Clinical update on nursing home medicine. $\mathrm{J}$ of the American Medical Directors Association 10: $530-53$.

9. Rolland Y, Dupuy C, van Kan GA, Gillette S, Vellas B (2011) Treatment strategies for sarcopenia and frailty. Medical Clinics of North America 95: 427-38.

10. Evans WJ, Morley JE, Argilés J, Bales C, Baracos V, et al. (2008) Cachexia: a new definition. Clinical Nutr 27: 793-9.

11. Bertini C (2006) Report of the Standing Committee on Nutrition at its 33rd Session Hosted by the World Health Organization Geneva Switzerland.

12. Lochs H, Allison SP, Meier R, Pirlich M, Kondrup J (2006) Introductory to the ESPEN guidelines on Enteral nutrition: Terminology definitions and general topics. Clinical Nutr 25: 180-186.

13. United-Nations Food and Agriculture Organization of the United-Nations.

14. Barker DJ, Hales CN, Fall CH, Osmond C, Kand P, et al. (1993) Type 2 (non-insulin-dependent) diabetes mellitus hypertension and hyperlipidaemia (syndrome X): relation to reduced fetal growth. Diabetologia 36: 62-67.

15. Barker DJ, Clark PM (1997) Fetal undernutrition and disease in later life. Rev Reprod 2: 105-112.

16. United Nations Standing Committee on Nutrition (2005) Fifth report on the world nutrition situation: nutrition for improved development outcomes Geneva.

17. Hotz C, Brown K (2004) Assessment of the risk of zinc deficiency in populations and options for its control: International Zinc Nutrition Consultative Group Technical Document 1.

18. Brown M, Funk C (2008) Food security under climate change. Science Magazine 319: 580-581.

19. Funk C, Brown ME (2009) Declining global per capita agricultural production and warming oceans threaten food security. Food Security 1: 271-289.

20. Funk C, Eilerts G, Davenport F, Michaelsen J (2006) A climate trend analysis of Kenya USGS Open-File Report.

21. FAO. Food security Policy Brief 2.

22. Lobell D, Field C (2007) Global scale climate crop yield relationships and the impacts of recent warming. Environmental Res Letters.

23. Von Braun W (2008) Food and financial crises: implications for agriculture and the poor In Food Policy Report IFPRI.

24. Hoddinott J Maluccio JA, Behrman JR, Flores R, Martorell R, (2008) Effect of a nutrition intervention during early childhood on economic productivity in Guatemalan adults. The Lancet 371: 411-416.

25. Fan S, Gulati A, Thorat S (2008) Investment subsidies and pro-poor growth in rural India. Agricultural Economics 39: 163-170.

26. Sala A, Pencharz P, Barr RD (2004) Children cancer and nutrition-A dynamic triangle in review. Cancer 100: 677-687.

27. Ladas EJ, Sacks N, Meacham L, Henry D, Enriquez L, et al. (2005) A multidisciplinary review of nutrition considerations in the pediatric oncology population: A perspective from Children's Oncology Group. Nutr Clinical Practice 20: 377-393.

28. Mosby TT, Barr RD, Pencharz PB (2009) Nutritional assessment of children with cancer. J Pediatr Oncology Nurs. 26: 186-197.
29. Han-Markey T (2000) Nutritional considerations in pediatric oncology. Semin Oncology Nurs 16: 146-151.

30. Brinksma A, Huizinga G, Sulkers E (2012) Malnutrition in childhood cance patients: A review on its prevalence and possible causes. Critical Reviews Oncology Haematology 83: 249-275.

31. Delbecque-Boussard L, Gottrand F, Ategbo S (1997) Nutritional status of children with acute lymphoblastic leukemia: A longitudinal study. American J Clinical Nutr 65: 95-100.

32. Skolin I, Axelsson K, Ghannad P, Hernell O, Wahline YB (1997) Nutrient intake and weight development in children during chemotherapy for malignant disease. Oral Oncology 33: 364-368.

33. Tyc VL, Vallelunga L, Mahoney S, Smith BF, Mulher RK (1995) Nutritional and treatment-related characteristics of pediatric oncology patients referred or not referred for nutritional support. Medical Podiatric Oncology 25: 379-388.

34. Green GJ, Weitzman SS, Pencharz PB (2008) Resting energy expenditure in children newly diagnosed with stage iv neuroblastoma. Pediatric Res 63: 332-336.

35. Bechard LJ, Adiv OE, Jaksic T (2006) Nutral supportive care In: Pizzo PA Poplack DG editors Principles and practice of pediatric oncology Philadelphia: Lippincott Williams and Wilkins.

36. Mauer AM, Burgess JB, Donaldson SS, Rickard KA, Stallings VA, et al. (1990) Special nutritional needs of children with malignancies: A review. J Parenteral and Enteral Nutr 14: 315-324.

37. Hughes WT, Price RA, Sisko F, Havron WS, Kafatos AG, et al. (1974) Proteincalorie malnutrition A host determinant for pneumocystis carinii infection. American J Diseases Children 128: 44-52.

38. Anema A, Vogenthaler N, Frongillo EA, Kadiyala S, Weiser SD (2009) Food insecurity and HIVIAIDS: current knowledge gaps and research priorities. Current HIVIAIDS Reports 6: 224-231.

39. Saloojee H, De Maayer T, Garenne ML, Kahn K (2007) What's new? investigating risk factors for severe childhood malnutrition in a high HIV prevalence South African setting. Scandinavian J of Public Health 69: 96-106.

40. Bunn JEG (2009) Severe acute malnutrition and HIV in African children. HIV Therapy 3: 595-611.

41. Nalwoga A, Maher D, Todd J, Karabarinde A, Biraro S, et al. (2010) Nutritiona status of children living in a community with high HIV prevalence in rura Uganda: a cross-sectional population-based survey. Tropical Medand Intl Health 15: 414-422.

42. Fergusson $P$, Tomkins A (2009) HIV prevalence and mortality among children undergoing treatment for severe acute malnutrition in sub-Saharan Africa: systematic review and meta-analysis. Transactions of the Royal Society of Tropical Medand Hygiene 103: 541-548.

43. Fergusson P, Tomkins A, Kerac M (2009) Improving survival of children with severe acute malnutrition in HIV-prevalent settings. Intl Health 1: 10-16.

44. Nakiyingi JS, Bracher M, Whitworth JAG, Ruberantwari A, Busingye J, et al (2003) Child survival in relation to mother's HIV infection and survival: evidence from a Ugandan cohort study. AIDS 17: 1827-1834.

45. Elia M, Zellipour L, Stratton RJ (2005) To screen or not to screen for adult malnutrition? Clinical Nutr. 24: 867-884

46. Kaiser MJ, Bauer JM, Ramsch C, Uter W, Guigoz Y, et al. (2010) Frequency of malnutrition in older adults: a multinational perspective using the min nutritional assessment. J of American Geriatrics Society 58: 1734-1738.

47. Kubrak C, Jensen L (2007) Malnutrition in acute care patients: a narrative review. Intl J of Nursing Studies 44: 1036-1054.

48. Vanderwee K, Clays E, Bocquaert I, Gobert M, Folens B (2010) Malnutrition and associated factors in elderly hospital patients: a Belgian cross-sectional multi-centre study. Clinical Nutr 29: 469-476.

49. Pauly L, Stehle P, Volkert D (2007) Nutritional situation of elderly nursing home residents. Zeitschrift fur Gerontologie und Geriatrie 40: 3-12.

50. Soini H, Muurinen S, Routasalo P, Sandelin E, Savikko N (2006) Oral and nutritional status - is the MNA a useful tool for dental clinics. The $\mathrm{J}$ of Nutr Health and Aging. 10: 495-499.

51. Cuervo M, Garcia A, Ansorena D, Sanchez-Villegas A, Martinez-Gon-zalez $M$, et al. (2009) Nutritional assessment interpretation on 22007 Spanish community-dwelling elders through the Mini Nutritional Assessment test. Public Health Nutr 12: 82-90. 
52. Petersen PE, Yamamoto $T$ (2005) Improving the oral health of older people: the approach of the WHO Global Oral Health Programme. Community Dentistry and Oral Epidemiology 33: 81-92.

53. De Visschere LM, Grooten L, Theuniers G, Vanobbergen JN (2006) Oral hygiene of elderly people in long-term care institutions - a cross- sectional study. Gerodontology 23: 195-204.

54. Marckmann P (1998) Nutritional status of patients on hemodialysis and peritoneal dialysis. Clinical Nephrology 29: 75-78.

55. Bergstrom J, Lindholm B (1993) Nutrition and adequacy of dialysis How do hemodialysis and CAPD compare? Kidney International supplement.

56. Cianciaruso B, Brunori G, Kopple JD, Traverso G, Panarello G, et al. (1995) Cross-sectional comparison of malnutrition in continuous ambulatory dialysis and hemodialysis patients. American J Kidney Diseases 26: 475-483.

57. Qureshi AR, Alvestrand A, Danielsson A, Divino-Filho JC, Gutierrez A, et al. (1998) Factors influencing malnutrition in hemodialysis patients $A$ crosssectional study. Kidney Intl 53: 773-782.

58. Kopple JD, Chumlea WC, Gassman JJ (1994) Relationship between GFR and nutritional status-results from the MDRD study. J of the American Society of Nephrology 5: 335 .

59. Ikizler TA, Greene JH, Wingard RL, Parker RA, Hakim RM (1995) Spontaneous dietary intake during progression of chronic renal failure. Kidney Intl 6: 13861391.

60. Muthayya S, Rah JH, Sugimoto JD, Roos FF, Kraemer K (2013) The global hidden hunger indices and maps: an advocacy tool for action. Plos One 8: 7860.

61. Haas JD, Beard JL, Murray-Kolb LE, del Mundo AM, Felix A, et al. (2005) Ironbiofortified rice improves the iron stores of non-anemic Filipino women. $\mathrm{J}$ of Nutr 135: 2823-2830.

62. Van Jaarsveld PJ, Faber M, Tanumihardjo SA, Nestel P, Lombard CJ, et al. (2005) b-Carotene rich orange-fleshed sweetpotato improves the vitamin $A$ status of primary school children assessed with modified-relative-doseresponse test. American J of Clinical Nutr 81: 1080-1087.

63. Low JW, Arimond M, Osman N, Cunguara B, Zano F, et al. (2007) A food-based approach introducing orangefleshed sweet potatoes increased vitamin A intake and serum retinol concentrations in young children in Rural Mozambique. $\mathrm{J}$ of Nutr 137: 1320-1327.

64. WHO (2008) Worldwide Prevalence of Anaemia 1993-2005 WHO Global Database on Anaemia Geneva: World Health Organization.

65. Nestel P, Bouis HE, Meenakshi JV, Pfeiffer W (2006) Biofortification of staple food crops. J Nutr 136: 1064-1067.

66. Carlson D, Nørgaard JV, Torun B, Cakmak I, Poulsen HD (2012) Bioavailability of trace elements in beans and zinc-biofortified wheat in pigs. Biol Trace Elem Res 150: 147-153.

67. Tako E, Laparra M, Glahn RP, Welch RM, Lei X, et al. (2009) Biofortified black beans in a maize and bean diet provide more bioavailable iron to piglets than standard black beans. J Nutr. 139: 305-309.

68. Tako E, Glahn RP (2011) White beans provide more bioavailable iron than red beans: studies in poultry (Gallus gallus) and an in vitro digestion/Caco-2 model. Intl J Vitamin Nutr Res. 81: 1-14.

69. Tako E, Blair MW, Glahn RP (2011) Biofortified red mottled beans (Phaseolus vulgaris) in a maize and bean diet provide more bioavailable iron than standard red mottled beans: Studies in poultry (Gallus gallus) and an in vitro digestion/ Caco-2 model. Nutr J 10: 113

70. Tako E, Hoekenga OA, Kochian LV, Glahn RP (2013) High bioavailability iron maize (Zea mays $\mathrm{L}$ ) developed through molecular breeding provides more absorbable iron in vitro (Caco-2 model) and in vivo Gallus gallus. Nutr J 12: 3.

71. De Rosa MC, Carelli AC, Galtieri A, Scatena R, Giardina B (2007) The plasma membrane of erythrocytes plays a fundamental role in the transport of oxygen carbon dioxide and nitric oxide and in the maintenance of the reduced state of the heme iron. Gene 398: 162-171.

72. Neumann CG, Gewa C, Bwibo NO (2004) Child nutrition in developing countries. Pediatric Annals. 33: 658-674.

73. Baltussen R, Knai C, Sharan M (2004) Iron fortification and iron supplementation are cost-effective interventions to reduce iron deficiency in four subregions of the world. J Nutr 134: 2678-2684.
74. Brinch-Pedersen H, Sørensen LD, Holm PB (2002) Engineering crop plants: getting a handle on phosphate. Trends Plant Sci 7: 118-125.

75. Lungaho MG, Mwaniki AM, Szalma SJ, Hart JJ (2011) Genetic and physiological analysis of iron biofortification in maize kernels. Plos One 6: 20429.

76. Tako E, Rutzke MA, Glahn RP (2010) Using the domestic chicken (Gallus gallus) as an in vivo model for iron bioavailability. Poultry Sci 89: 514-521.

77. Welch RM, House WA, Beebe S, Cheng Z (2000) Genetic selection for enhanced bioavailable levels of iron in bean (Phaseolus vulgaris $L$ ) seeds. J of Agric Food Chem 48: 3576-3580.

78. Holzapfel WH (2002) Appropriate starter culture technologies for small-scale fermentation in developing countries. Intl J Food MicroBio 75: 197-212.

79. Muchoki CN, Lamuka PO, Imungi JK (2010) Reduction of nitrates oxalates and phenols in fermented solar-dried stored cowpea (vigna unguiculata) leaf vegetables. African J Agricultural Nutr Dev 10: 4398-4412.

80. Zimmermann MB, Chassard C, Rohner FN, Goran EK, Nindjin C, et al. (2010) The effects of iron fortification on the gut microbiota in African children: a randomized controlled trial in C te d'Ivoire. American J of Clinical Nutr 92: 1406-1415.

81. Smith MI, Yatsunenko T, Manary MJ, Trehan I, Mkakosya R, et al. (2013) Gutmicrobiomes of Malawian twin pairs dis- cordant for kwashiorkor. Sci 339 548-554.

82. De Filippo C, Cavalieri D, Di Paola M, Ramazzotti M, Poullet JB, et al. (2010) Impact of diet in shaping gut microbiota revealed by a comparative study in children from Europe and rural Africa. Proceedings of the National Academy of Scis USA 107: 14691-14696.

83. Grzeskowiak L, Collado MC, Mangani C, Maleta K, Laitinen K, et al. (2012) Distinct gut microbiota in southeastern African and northern European infants. $\mathrm{J}$ of Pediatric Gastroenterology and Nutr 54: 812-816.

84. Nout MJR (2009) Rich nutrition from the poorest - cereal fermentations in Africa and Asia. Food MicroBio 26: 685-692.

85. Holzapfel WH (1997) Use of starter cultures in fermentation on a household scale. Food Control 8: 241-258.

86. WHO (2013) Guideline: Updates on the management of severe acute malnutrition in infants and children Geneva: World Health Organization.

87. WHO (1999) Management of severe malnutrition: a manual for physicians and other senior health workers.

88. Manary MJ (2006) Local production and provision of ready-to-use therapeutic food (RUTF) spread for the treatment of severe childhood malnutrition. Food Nutr Bulletin 27: S83-89.

89. Briend A, Lacsala R, Prudhon C, Mounier B, Grellety Y, et al. (1999) Readyto-use therapeutic food for treatment of Marasmus. Lancet 353: 1767-1768.

90. Diop EIDN, Ndour MM, Briend A, Wade S (2003) Comparison of the Efficacy of a Solid Ready to Use Food and a Liquid Milk-based Diet for the Rehabilitation of Severely Malnourished Children: A Randomized Trial. American J Clinical Nutr 78: 302-307.

91. Ciliberto MA, Sandige HN, Ndekha MJ, Ashorn P, Briend A, et al. (2005) Comparison of home-based therapy with ready-to-use therapeutic food with standard therapy in the treatment of malnourished Malawian children: a controlled clinical effectiveness trial. American J Clinical Nutr 81: 864-870.

92. Navarro-Colorado C, Laquière $S$ (2005) Use of solid ready-to-use-therapeuticfood (BP100) vs F100 milk for rehabilitation of severe malnutrition during emergencies: a clinical trial in Sierra Leone. Field Exchange. 24: 22-24.

93. Eklund M, Girma T (2008) Effectiveness of integrated outpatient care of severe acute malnutrition in Ethiopia. Field Exchange 34: 7-8.

94. Linneman Z, Matilsky D, Ndekha M (2007) A large-scale operational study of home-based therapy with ready-to-use therapeutic food in childhood malnutrition in Malawi Matern. Child Nutr 3: 206-215.

95. Sadler K, Kerac M, Collins S, Khengere H, Nesbitt A (2008) Improving the management of severe acute malnutrition in an area of high HIV prevalence. $J$ Tropical Pediatrics 54: 364-369.

96. Defourny G, Seroux I, Abdelkader G, Harczi (2007) Management of moderate acute malnutrition with RUTF in Niger. Field Exchange 31: 2-4.

97. Gaboulaud V, Dan-Bouzoua N, Brasher C, Fedida G, Gergonne B, et al. (2007) Could nutritional rehabilitation at home complement or replace centre-based therapeutic feeding programmes for severe malnutrition? J Tropical Pediatrics 53: 49-51. 
98. Dibari F, Le Galle I, Ouattara A, Bahwere P, Seal A (2008) Qualitative Investigation of Plumpy'nut Consumption in Adults Enrolled in an MoH/MSF Programme in Kenya Report on MSF Scientific Day: 'Research shaping the way we work.

99. Enserink M (2008) The peanut butter debate. Sci 322: 36-38.

100. Floros JD, Newsome R, Fisher W, Barbosa-Canovas GV, Chen H, et al. (2010) Feeding the world today and tomorrow: the importance of food Sci and technology An IFT scientific review Comp Rev. Food Sci. 9: 572-599.

101. Rickman J, Bruhn C, Barrett D (2007) Nutritional comparison of fresh frozen and canned fruits and vegetables I Vitamins $C$ and $B$ and phenolic compounds. J Sci Food Agric. 87: 930-944.

102. Rickman J, Barrett D, Bruhn C (2007) Nutritional comparison of fresh frozen and canned fruits and vegetables II Vitamin A and carotenoids vitamin E minerals and fiber. J Sci Food Agric. 87: 1185-1196.

103. Dwyer JT, Fulgoni VL, Clemens RA, Schmidt DB, Freedman MR (2010) Is "processed" a four-letter word? The role of processed foods in achieving dietary guidelines and nutrient recommendations. Advanced Nutr 3: 536-548.

104.Parfitt J, Barthel M, Macnaughton S (2010) Food waste within food supply chains: quantification and potential for change to 2050 Philos Trans. Royal Society 365: 3065-3081.

105. Gustavsson J, Cederberg C, Sonesson U, van Otterdijk, Meybeck A. Global food losses and food waste: Extent Causes and Prevention. Food and Agric Organization of the United Nations, Rome.

106. Buzby JC, Hyman J (2012) Total and per capita value of food loss in the United States Food Policy 37: 561-570.

107. Allen L, de Benoist B, Dary O, Hurrell R (2006) Guidelines on Food Fortification with Micronutrients World Health Organization and Food and Agricultural Organization of the United Nations.

108. World Bank. Enriching Lives: Overcoming Vitamin and Mineral Malnutrition in Developing Countries Development in Practice Series The World Bank Washington DC. 1994

109. Backstrand JR (2002) The history and future of food fortification in the United States: a public health perspective. Nutr Reviews 60: 15-26.

110. Kowalska I, Sady W (2014) Assessment of biofortification with iodine and selenium of lettuce cultivated in the NFT hydroponic system. Scientia Horti 166: 9-16.

111. Kapolna E, Laursen KH, Husted S, Larsen EH (2012) Bio-fortification and isotopic labelling of Se metabolites in onions and carrots following foliar application of Se and $77 \mathrm{Se}$. J of Food Chem 133: 650-657.

112. Rana A, Joshi M, Prasanna R, Singh $Y$, Nain L (2012) Biofortification of wheat through inoculation of plant growth promoting rhizobacteria and cyanobacteria. European J. of Soil Bio 50:118-126.

113. Mabesa RL, Impa SM, Grewal D, Johnson-beebout SE (2013) Contrasting grain-Zn response of biofortification rice ( Oryza sativa $L$ ) breeding lines to foliar Zn application. Field Crops Res. 149: 223-233.

114. Duran P, Acuña JJ, Jorquera MA, Azcón R, Borie F, et al. (2013) Enhanced selenium content in wheat grain by co-inoculation of selenobacteria and arbuscular mycorrhizal fungi : A preliminary study as a potential Se bioforti fi cation strategy. J. of Cereal Sci 57: 275-280.

115. Pellegrino E, Bedini S (2014) Enhancing ecosystem services in sustainable agriculture : Biofertilization and bioforti fi cation of chickpea (Cicer arietinum $L$ ) by arbuscular mycorrhizal fungi. Soil Bio and BioChem 68: 429-439.

116. Sady W (2012) Influence of iodine form and application method on the effectiveness of iodine biofortification nitrogen metabolism as well as the content of mineral nutrients and heavy metals in spinach plants (Spinacia oleracea $L$ ). Scientia Horti 143: 176-183.

117. Ramesh A, Sharma SK, Sharma MP, Yadav N, Joshi OP (2014) Inoculation of zinc solubilizing Bacillus aryabhattai strains for improved growth mobilization and biofortification of zinc in soybean and wheat cultivated in Vertisols of central India. Applied Soil Ecology 73: 87-96.

118. Sanmartín C, Garmendia I, Romano B, Díaz M, Antonio J, et al. (2014) Mycorrhizal inoculation affected growth mineral composition proteins and sugars in lettuces biofortified with organic or inorganic selenocompounds. Scientia Horti 180: 40-51.
119. Rahman MM, Erskine W, Zaman MS, Thavarajah P. Thavarajah D, et al. (2013) Selenium bioforti fi cation in lentil ( Lens culinaris Medikus subsp culinaris ): Farmers' field survey and genotype $\times$ environment effect. Food Res Intl 54: 1596-1604.

120. Bañuelos GS, Arroyo I, Pickering IJ, In S, Freeman JL (2015) Selenium biofortification of broccoli and carrots grown in soil amended with Se-enriched hyperaccumulator Stanleya pinnata food chemistry. J of Food Chem 166: 603-608.

121. Fernandes $P$, Faquin V, William A, Volpi K, Boldrin F, et al. (2013) Soil and foliar application of selenium in rice biofortification. J. of Food Composition and Analysis 31: 238-244.

122.Zhang Y, Sun Y, Ye Y, Karim R, Xue Y, et al. (2012) Zinc biofortification of wheat through fertilizer applications in different locations of China. Field Crops Res 125: 1-7.

123. Gras ML, Vidal D, Betoret N, Chiralt A, Fito P (2003) Calcium fortification of vegetables by vacuum impregnation Interactions with cellular matrix. Journal of food engineering 56 : $279-284$.

124. Tripathi B, Platel K (2013) Feasibility in fortification of sorghum (Sorghum bicolor $L$ Moench ) and pearl millet ( Pennisetum glaucum ) flour with iron. LWT - Food Sci and Tech 50: 220-225.

125. Tripathi B, Platel K (2010) Finger millet ( Eleucine coracana ) flour as a vehicle for fortification with zinc. J of Trace Elements in Medand Bio 24: 46-51.

126. Tripathi B, Platel K (2010) Fortification of sorghum ( Sorghum vulgare ) and pearl millet ( Pennisetum glaucum ) flour with zinc. J of Trace Elements in Medand Bio 24: 257-262.

127.López-nicolás R, Frontela-saseta C, González-abellán R, Barado-piqueras A Perez-conesa D, et al. (2014) Folate fortification of white and whole-grain bread by adding Swiss chard and spinach Acceptability by consumers. LWT Food Sci and Tech 59: 263-269.

128. Gangadharan D, Nampoothiri KM (2011) Folate production using Lactococcus lactis ssp cremoris with implications for fortification of skim milk and fruit juices. LWT-Food Sci and Tech 44: 1859-1864.

129. Kam K, Murray JM, Arcot J, Ward R (2012) Fortification of parboiled rice with folic acid : Consumer acceptance and sensory evaluation. FRIN 49: 354-363.

130.Renuka B, Kulkarni SG, Vijayanand P, Prapulla SG (2009) Fructooligosaccharide fortification of selected fruit juice beverages : Effect on the quality characteristics. LWT - Food Sci and Tech 42: 1031-1033.

131. Singh G, A KM (2008) Influence of calcium fortification on sensory physical and rheological characteristics of fruit yogurt 41: 1145-1152.

132. Tripathi B, Platel K (2011) Iron fortification of finger millet (Eleucine coracana) flour with EDTA and folic acid as co-fortificants. Food Chem 126: 537-542.

133. Raouche S, Naille S, Dobenesque M, Bot A, Jumas J (2009) Iron fortification of skim milk: Minerals and Fe Mossbauer study. International dairy journal 19: $56-63$.

134. Gupta C, Chawla P, Arora S, Tomar SK, Singh AK (2015) Food Hydrocolloids Iron microencapsulation with blend of gum arabic maltodextrin and modified starch using modified solvent evaporation method Milk fortification 43: 622-628.

135. Aquilanti L, Kahraman O, Zannini E, Osimani A, Silvestri G, et al. (2012) Response of lactic acid bacteria to milk fortification with dietary zinc salts. Intl. Dairy J 25: 52-59.

136. Kolanowski W, Wei J (2007) Sensory quality of dairy products fortified with fish oil. International Dairy Journal 17: 1248-1253.

137. Arif $S$, Vieth $R$ (2007) Vitamin $D_{3}$ fortification and quantification in processed dairy products. International Dairy Journal 17: 753-759.

138. Yong L, Chan CH, Garcia C, Sopade PA (2011) Weighing up whey fortification of foods: Implications for kinetics of starch digestion and estimated glycemic index of model high-protein-low-carbohydrate food systems. Carbohydrate Polymers 84: 162-172.

139. Prom-u-thai C, Rerkasem B, Cakmak I, Huang L (2010) Zinc fortification of whole rice grain through parboiling process. Food Chem 120: 858-863. 